\title{
Viral Marketing Adoption among Egyptian Travel Agents: Perceived Benefits and Barriers
}

\author{
Mohammad S. Soliman \\ Lecturer in Tourism Studies Department \\ Faculty of Tourism and Hotels, Fayoum University, Egypt
}

\begin{abstract}
Tourism organizations have been looking for new tools to reach target markets in a more efficient and effective way. While developing their marketing tools, they are now using viral marketing, which has generated a lot of excitement in recent years and can provide enormous benefits to tourism companies in many countries such as Egypt. This research aims to highlight the perceived benefits of viral marketing adoption to Egyptian travel agents and to determine the perceived barriers to viral marketing adoption in these agents. Quantitative approach is used to achieve the aims of this study. Questionnaire forms were collected from marketing managers in travel agencies category 'A' in Egypt. Surveyed agents showed that marketing, managerial, and customer- related benefits are among the benefits offered to Egyptian travel agents by viral marketing adoption. Additionally there are organizational, environmental, and technical barriers to adopt viral marketing in travel agents in Egypt.
\end{abstract}

Keywords: Viral Marketing; Benefits; Barriers; Travel Agencies; Egypt

\section{Introduction}

Tourism and internet are two correlated elements in recent years. The current improvements in internet make vast changes in tourism industry's strategies, structure, and operations (Alipour, Hajaliakbari, and Javanbakht, 2011). In addition, tourism has probably been the most affected industry by internet. This is to be expected, as tourism depends on the distribution of information about its products and services, which is exactly what internet is good for (Guthan, 2002). Moreover, the intense global competition in tourism industry forces organizations to develop a strong, unique, and competitive internet marketing approaches to win new markets (Konecnik, 2002; Riege, Perry, and Go, 2002). One of the most exciting and promising e-marketing techniques is viral marketing, which is the tactic of creating a process where interested customers can market to each other. It can be thought of as a diffusion of information about the tourism product and its adoption over the network (Dinh, Nguyen, and Thai, 2012; Leskovec, Adamic, and Huberman, 2007; Subramani and Rajagopalan, 2003)

Viral marketing has become the defining marketing trend of the last decade and the best option to achieve the organizations objectives (Scott, 2007; Skrob, 2005; Steyer, Renaud, and Pascale, 2007; Watts, Peretti, and Frumin, 2007). According to Alkharabsheh, et al. (2011), there is the impact of viral marketing on the consumer decision to buy the tourism product, and the information sent through the websites relevant, credible, and reliable, thereby forming a positive image of the tourism organization. By using viral marketing tactics carefully, marketers can gain an excellent profit as they increase the reach of their marketing message to a targeted group far beyond their original audience (Khosravani, 2009). Despite the fact that viral marketing can be a successful means of tourism marketing communication, it is a fairly new topic and facts about its nature, characteristics and dimensions have yet to be agreed and established (Cruz and Fill, 2008) in tourism sector in Egypt. Viral marketing is still only a limited understanding of how it works in many organizations around the world (Bannan, 2000). In addition, it is still considered to be at a premature phase of development, therefore information about its behaviour and magnitude has yet to be clearly set upon and determined. Moreover, limited research has been done on viral marketing perception to such marketing techniques in many countries such as Egypt (Best, 2009; Xavier and Summer, 2009). Thus, this paper aims to determine the significant benefits selected by Egyptian travel managers to adopt viral marketing in their agencies. In addition, it seeks to discover the most frequent barriers to viral marketing adoption in the Egyptian travel agents. This paper is organized as follows. Following an introductory section, a review of related literature is presented. This includes viral marketing and its benefits and barriers. In the next section, research methodology is presented. Data collection process and instrumentation are discussed in the following section. Next, the research hypotheses are examined and tested with factor analysis and regression analysis. The results are presented following which discussions and concluding remarks given.

\section{Viral Marketing}

The term "viral marketing" was developed in a 1997 by Jurvetson and Draper. It was coined to describe a 'networkenhanced word of mouth' and was first to explain the free email service provided by Hotmail, beginning with its launch in 1996. The word "viral" was used because of the pattern of rapid adoption through word of mouth (WOM) networks (Grifoni, D'Andrea, and Ferri, 2013; Jurvetson, 2000; Jurvetson and Draper, 1997; Thevenot, Watier, and Team Member, 2001). 
Viral marketing is different from the traditional WOM. Generally, traditional WOM has been conceptualized and explored as interpersonal informational exchange between individuals familiar to each other (Yasin and Zahari, 2011). Off the internet, viral marketing has been referred to as 'WOM creating buzz ', 'network marketing'. Nevertheless, on the internet, for better or worse, called "viral marketing" (Deepa and Thenmozhi, 2013; Dobele, Lindgreen, Beverland, Vanhamme, and Wijk, 2007; Herbig, 2011; Plummer, Rappaport, Hall, and Barocci, 2007; Wilson, 2012). Therefore, viral marketing includes the online or offline activities performed by managers and marketers to make the message viral and have e-WOM as effect, with its exponentially growing message diffusion. It no longer represents only a marketing-to-consumer communication, but also a consumer-to-consumer communication, encouraged by marketers (Chiu, Yi-Ching Hsieh, Ya-Hui Kao, and Lee, 2007; Woerndl, Papagiannidis, Bourlakis, and $\mathrm{Li}, 2008)$.

Even if viral marketing has grown rapidly since then, different studies still presents various definition of the term (Grifoni et al., 2013). Viral marketing can be defined as making email into a form of advocacy or WOM referral endorsement from one customer to other prospective customers (Dobele, Tolemanb, and Beverlandb, 2005; Kozinets, Kristine, Andrea, and Sarah, 2010; Laudon and Traver, 2001; Porter and Golan, 2006). Phelps et al. (2004) define viral marketing as the process of encouraging honest communication among consumer networks. In Armstrong and Kotler's (2011) viral marketing is the internet version of WOM marketing - Web sites, videos, email messages, or other marketing events that are so infectious that customers will want to pass them along to friends. Moreover, viral marketing is any form of marketing techniques that spread like a virus, using some sort of social networks such as YouTube, Facebook, and Twitter, which include information about the company and its brand message, goods or services (Anderson, 2008; Anonymous, 2010; Argentini and Barnes, 2009; Datta, Dababrata N. Chowdhury, and Chakraborty, 2005; Deepa and Thenmozhi, 2013; Domingos, 2005; Khosravani, 2009; Leskovec, et al., 2007).

From a marketing perspective, viral marketing is the process of encouraging individuals to pass along favourable or compelling marketing information they receive in a hypermedia environment: information that is favourable or compelling either by design or by accident (Patel, 2007; Schiffman and Kanuk, 2010). Furthermore, viral marketing is definitely shaping up as a credible, strategic synthesis between WOM techniques and top-down advertainment-style approaches to increase product awareness and adoptions. Used wisely, with a strategic end goal in mind, it can be a key success driver within any brand's overall marketing activity (Bampo, Ewing, Mather, Stewart, and Wallace, 2008; Kirby, 2004; Panchanathan, 2005; Xiong and Hu, 2011). Boon and Kurtz (2011) describes viral marketing as efforts that allow satisfied customers to spread the message about tourism products to other customers.

According to Sohn et al. (2013) viral marketing is a marketer-initiated consumer activity that spreads a marketing message unaltered across a market or segment in a limited time period mimicking an epidemic. The process of the viral marketing is illustrated in Figure 1.

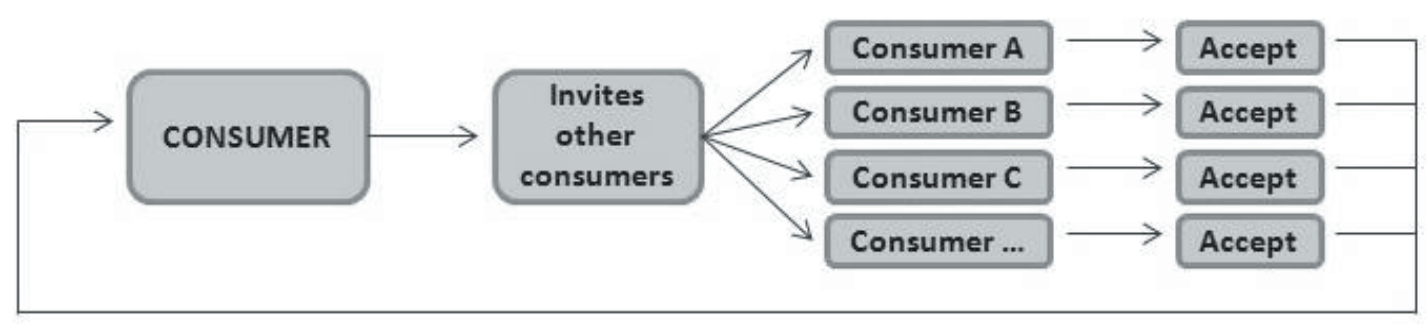

Figure (1): The viral marketing process, Source: (Grifoni, D'Andrea, and Ferri, 2013)

Viral marketing uses e-mail as the main tool because so many people routinely communicate with others through it (Yasin and Zahari, 2011). In addition, it has many tools, such as video clips, interactive flash, interactive websites, images, mobile messaging such as SMS (Dobele et al., 2007; Ho and Dempsey, 2009), mini-sites, online games, online greeting cards (Cruz and Fill, 2008; Van der Lans, Van Bruggen, Eliashberg, and Wierenga, 2010), polls, quizzes, audio fragments, e-mail newsletters, e-mail closures and tell-a-friend options as alternative forms of viral marketing appearances (Sprong, 2010).

\section{Benefits of Viral Marketing Adoption among Travel Agents}

With the evolution of internet, the interactivity among the virtual community members played important roles when consumers want to find information about tourism destinations to do some decision-making. The theory behind the value of viral marketing is that exponential numbers of potential customers can receive the company message which includes the information (Bonera, 2010; Bruyn and Lilien, 2008). Viral marketing aims to make contact with as many customers as possible with which businesses can connect (Helm, 2000). Recognizing this opportunity, several world- 
class companies and brands have jumped on the viral marketing bandwagon, such as Budweiser, eBay, and Nestlé (Gruen, Osmonbekov, and Czaplewski, 2006; Patel, 2007).

Another advantages of viral marketing for tourism companies are; increased potential for impact on the market, and taken advantage of existing resources (Anonymous, 2010; Panchanathan, 2005). In addition, it can drive sales, reduce marketing costs, and reach target consumer segments (Dobele et al., 2005). Viral marketing encourages WOM promotion by capitalizing on social networks and customers' desire to contribute to and share message content with their peers (Castronovo and Huang, 2012). The most significant benefit of viral marketing is that it allows consumers to pass along a marketing message in an easy manner by spreading it like a biological virus (Grifoni et al., 2013). According to Deepa and Thenmozhi (2013) viral marketing is popular because of the ease of executing the marketing campaign, relatively inexpensive, (compared to direct mail), good targeting, and the high and rapid response rate.

Furthermore, there are several advantages of viral marketing over traditional mass media. For example, since in viral marketing where users are socially connected, message senders tend to have knowledge to select receivers with possible desired reactions to the message. Therefore, it can enable tourism companies to reach customers on a larger scale, including customers that they would not be able to reach otherwise before. Further, a behavioural response to a viral message is potentially more quantifiable than in other mass communication forms because of the exponential growth (Bampo et al., 2008; Ferguson, 2008; Subramani and Rajagopalan, 2003). Fritz (2004) presented several noneconomic benefits of viral marketing such as; customer acquisition, customer satisfaction, customer loyalty, and degree of popularity.

The value of viral marketing is largely related to its use of existing digital networks to increase brand image (Dinh et al., 2012). The technique is valuable for both customers and companies. Customers get things they want, such as discounts, free products, or valuable information. For companies, it is an inexpensive way to increase their customer base. Viral marketing's value proposition is branding. Having a company or product name exposed to millions of people may increase brand awareness, regardless of whether the viral promotion is acted upon. Viral marketing may help companies gain first-mover advantage if they can delay revenue maximization and focus on establishing brand awareness and building barriers to switching for customers (Bonera, 2010; Richter, 2012; Thevenot et al., 2001).

\section{Barriers to Viral Marketing Adoption in Travel Agents}

Small and medium-sized enterprises (SMEs) are recognized by their unwillingness to take risks and they are costconscious, due to their limited access to capital resources. These characteristics have supported the description of SMEs as slow adopters of technology in general (Beekhuyzen, Hellens, and Siedle, 2005; Zhang and Morrison, 2007). In a study carried out by Johnstone and Wright (2004) on the barriers affecting the implementation of internet systems and procedures in different countries. It was revealed the following barriers; high cost of installing infrastructure; high price of technology, large investment requirements and liquidity constraints; uncertain return on investment (ROI); limited worker expertise caused by a general shortage of highly skilled workers and insufficient training. In addition, lack of management vision, support, and enthusiasm in the adoption of internet technology, inability to outsource IT expertise; and bad experiences in the past are other barriers.

These findings is in line with Abou-Shouk (2012) who studied E-commerce adoption in SMEs tourism enterprises in Egypt. He found similar findings citing that lack of knowledge and awareness of technology adoption, limited resources, resistance to change and risk taking reluctance, business characteristics, business planning, and strategy are barriers to E-commerce adoption in Egypt. Moreover, lack of technological readiness, legal concerns, and security issues, business environment, lack of external support and successful role models, technology attributes, and the cost of technology implementation cited as barriers to adopt E-commerce. Further, SME owners pursuing unclear business strategies often contribute to their businesses losing sight of the value of adopting internet technology (Migiro and Adigun, 2005). Other studies consider the lack of knowledge as a factor made manifest in a lack of awareness; advice and support or having a staff compliment without the necessary internet skills (Kohn and Husig, 2006; Stansfield and Grant, 2003).

Other researchers have highlighted the absence of a national and international regulatory framework related to privacy and security as a major concern for SMEs not adopting the internet applications such as viral marketing (Lewis and Cockrill, 2002). Moreover, lack of training, capital and understanding of the potential benefits brought about by IT have been cited as key barriers to the adoption of viral marketing by SMEs (Migiro and Adigun, 2005). Viral marketing also presents limitations related to: technical problems or poor technological implementation (Bernoff and Li, 2008); lack of control over message and reach, legal issues dealing with privacy and harassment (Chaffey, 2006); and lack of measurement and uncharted growth in unexpected areas (Grifoni et al., 2013). Table 1 shows the generally accepted barriers to adopt viral marketing in travel agents as follows. 
Table (1): Barriers to viral marketing adoption in travel agents

\begin{tabular}{|c|c|}
\hline $\begin{array}{l}\text { Size or } \\
\text { quantity }\end{array}$ & $\begin{array}{l}\text { If viral content is a video clip or streaming video, it may be too large for the } \\
\text { recipient to receive. }\end{array}$ \\
\hline Media format & $\begin{array}{l}\text { A viral marketing campaign will be unsuccessful if the message is in a } \\
\text { format that most people cannot use; for example if particular software is } \\
\text { needed that is not widely used, then people will not be able to open or view } \\
\text { the message. }\end{array}$ \\
\hline $\begin{array}{l}\text { Using Email } \\
\text { attachments }\end{array}$ & $\begin{array}{l}\text { Many people receive viral marketing messages. Anti-virus software or } \\
\text { firewalls can prevent people from receiving or viewing such attachments. }\end{array}$ \\
\hline $\begin{array}{l}\text { Difficult } \\
\text { mechanism }\end{array}$ & $\begin{array}{l}\text { For a viral marketing campaign to be successful, it must be easy to use. For } \\
\text { example, if the promotion is some sort of game or contest, then asking for } \\
\text { referrals should be an option immediately after the game, not as a condition } \\
\text { to play. }\end{array}$ \\
\hline Sabotage & $\begin{array}{l}\text { Especially in the case of undercover style marketing campaigns, the } \\
\text { discovery of the marketing nature of a popular campaign may cause the } \\
\text { same social networks to inform people of the commercial intent of the } \\
\text { meme, and promote a formal or informal boycott of the company or product } \\
\text { in question. }\end{array}$ \\
\hline $\begin{array}{l}\text { Lack of } \\
\text { control }\end{array}$ & $\begin{array}{l}\text { - Uncontrollable nature, especially audience reach, content and few } \\
\text { possibilities to measure success } \\
\text { - Total loss of control especially timing and content and spam } \\
\text { - Lack of control mechanism: } \\
\text { - No control over distortion process } \\
\text { - Adverse selection of consumers }\end{array}$ \\
\hline $\begin{array}{l}\text { Potential } \\
\text { negative } \\
\text { impact }\end{array}$ & $\begin{array}{l}\text { - Risk of backlash and negative brand impact } \\
\text { - Negative WoM can occur } \\
\text { - Negative WoM leads to boycott, ruin and unfavorable attitudes } \\
\text { - Hate sites } \\
\text { - } \text { May lead to negative perception of brands }\end{array}$ \\
\hline $\begin{array}{l}\text { Consumer } \\
\text { dependency }\end{array}$ & - Consumers unwilling to provide referrals unless there is some return \\
\hline $\begin{array}{l}\text { Lack of legal } \\
\text { standards }\end{array}$ & - Emerging legal issues have to be taken into consideration \\
\hline $\begin{array}{l}\text { Lack of } \\
\text { ethical } \\
\text { standards }\end{array}$ & $\begin{array}{l}\text { - Consumers may feel exploited, cheated, used } \\
\text { - Emerging ethical issues need to be considered } \\
\text { - Consumer privacy invasion }\end{array}$ \\
\hline $\begin{array}{l}\text { Other risks/ } \\
\text { barriers }\end{array}$ & $\begin{array}{l}\text { - Easily copied by competitors } \\
\text { - Can attract unwanted visitors to website } \\
\text { - Too much traffic can crash website } \\
\text { - Consumers talking - can drive business to the ground }\end{array}$ \\
\hline
\end{tabular}

Source: Koning 2006; GlobalOneness 2013; Dobele, Tolemanb, and Beverlandb 2005; Helm 2000; Kaikati and Kaikati 2004; Mindcomet. 2008; Welker 2002; Kwiatkowska 2009

At the same time, a marketer would not like a viral campaign to grow into an uncontrolled flu. It is important to monitor the spread and have a fair idea as to where it is heading. A successful viral marketing campaign can sometimes be hard to control (Deepa and Thenmozhi, 2013).

\section{Research Methodology}

To achieve the research objectives, and built upon the aforementioned discussion, the research hypotheses are developed to include two main categories of factors that affect the process of viral marketing adoption: benefits of adoption and barriers to adoption, as follows;

H1. There is a positive causal relationship between the perceived benefits of adoption and viral marketing adoption in Egyptian travel agents.

$\mathrm{H} 2$. There is a negative causal relationship between the perceived barriers to adoption and viral marketing adoption in Egyptian travel agents.

Quantitative approach is employed to test the hypotheses of this study and to categorize the significant perceived benefits and barriers to adopt viral marketing among travel agents in Egypt. Drawing on the literature review, a questionnaire was developed to capture the respondents' views on the benefits of and barriers to viral marketing 
adoption. The primary form was prepared in English language then validated by expert panel. The panel included three Egyptian professors, in addition to some professionals in the career, and $15 \mathrm{PhD}$ students specialized in tourism studies to check face validity, then it has been translated into Arabic language to check questions comprehensiveness, and then it has been translated back into English language to compare the two forms and avoid translations misleading issues (Saunders, Thornhill, and Lewis, 2009).

Based on the feedback of the reviewers, the questionnaire was revised to address some reliability issues. The final form of the questionnaire comprised four partitions. The first part includes viral marketing adoption in Egyptian travel agencies. The second part includes the measurement of the variables related with benefits (13 items) of viral marketing adoption. The third part includes the variables related with barriers (14 items) to viral marketing adoption. Each variable in the second part and the third part was measured by the five-point Likert scale, ranging from 1 (strongly disagree) to 5 (strongly agree). The fourth part of the questionnaire includes the demographic profile (age, total working experience, work experience in present company).

A pilot study involving 40 travel agents was then conducted in order to determine the significant benefits and barriers among travel agents. Significant benefits and barriers are those, which are frequently repeated in the form. Data were utilised for the testing of validity and reliability of the measurement instruments. The Cronbach's alpha (reliability analysis) values for the variables were 0.748 for the 13 items of benefits and 0.718 for the 14 items of barriers included in the final form for travel agents. Overall, the pilot test confirmed that the measurements used for this study have achieved an adequate level of reliability.

Regarding the sample, there are three categories of travel agents in Egypt; Category (A), companies that organise packages for groups or land individuals, inside or outside Egypt, organise all other related items of these packages and execute planned packages of other tour operators. Category (B) includes companies that sell, issue transportation tickets (air, water and land transportation) and move luggage besides being agents for airlines and other companies. Category (C) includes companies that operate transportation means; air, land and water ones to transport tourists (Hassan and Soliman, 2013).

The sample of the study covers category (A) travel agencies. There are a total of 2098 travel agents in category (A) in Egypt (Egyptian Travel Agents Association, 2013). For the high percentage of travel agents Greater Cairo-based (1697 agents-80\%), Greater Cairo TAs category (A) is selected to be the sample of this study. The questionnaire form has to be delivered and collected from selected agents. 130 forms were collected from travel agents managers, and these forms were found free of missing data and valid for analysis purposes. Data collection was carried out during the period of July-November 2013. Mean statistics were used to count the agreed benefits and barriers then factor analysis and regression analysis were conducted to cover the aims of this study.

\section{Results and Discussion}

\section{Viral marketing adoption in Egyptian travel agents}

Results show that 48\% (30\% strongly disagree, $18 \%$ disagree) from the respondents don not adopt viral marketing in tourism marketing strategy and 52\% (48\% agree, 4\% strongly disagree,) of them use some tools of viral marketing such as; e-mail, video clips, social media (Facebook, Twitter, YouTube), and mobile messaging such as SMS. From descriptive analyses and using mean scores of managers' opinions in Egyptian travel agents; it is clear that agents are neutral of viral marketing adoption as the mean score is 2.78 that means neutral.

\section{Benefits of and barriers to viral marketing adoption in travel agents}

The first research objective seeks the perceived benefits mentioned by travel agents' managers. From descriptive analyses and using mean scores of managers' opinions in travel agents (Table 2); it is clear that agents agreed the 13 benefits of viral marketing adoption as the mean scores range from 4 to 5 that means agree and strongly agree. The second research objective examines the perceived barriers to viral marketing adoption. From descriptive analyses and using mean scores of managers' opinions in travel agents (Table 2); it is clear that managers agreed the 14 barriers as the mean scores range from 4 to 5 that means agree and strongly agree. 
Mohammad S. Soliman

Table (2): Statistics of benefits of and barriers to viral marketing adoption in travel agents

\begin{tabular}{|c|c|c|}
\hline & Mean & Std. Error \\
\hline \multicolumn{3}{|c|}{ The perceived benefits of viral marketing adoption in Egyptian travel agencies: } \\
\hline 1- Sales, revenue and profits growth & 4.00 & .100 \\
\hline 2- Increasing competitive advantage & 4.04 & .119 \\
\hline 3- Ease of carrying out transactions & 4.11 & .063 \\
\hline 4- Reducing response time & 4.36 & .042 \\
\hline 5- Encouraging customer loyalty & 4.35 & .047 \\
\hline 6- Reaching target consumer segments & 4.28 & .073 \\
\hline 7- Increasing brand awareness & 4.51 & .049 \\
\hline 8- Taken advantage of existing resources & 4.72 & .045 \\
\hline $\begin{array}{l}\text { 9- Establishing reputation in the global } \\
\text { markets }\end{array}$ & 4.08 & .065 \\
\hline 10- Improving the company image & 4.00 & .059 \\
\hline $\begin{array}{l}\text { 11- Increasing potential for impact on the } \\
\text { market }\end{array}$ & 4.35 & .047 \\
\hline $\begin{array}{l}\text { 12- Discounts, free products, or valuable } \\
\text { information for customers }\end{array}$ & 4.30 & .046 \\
\hline 13- Improving customer satisfaction & 4.12 & .129 \\
\hline \multicolumn{3}{|c|}{ The perceived barriers to viral marketing adoption in Egyptian travel agencies: } \\
\hline $\begin{array}{l}\text { 1. Lack of Knowledge and/or awareness } \\
\text { of viral marketing benefits }\end{array}$ & 4.00 & .144 \\
\hline $\begin{array}{l}\text { 2. Limited available resources for viral } \\
\text { marketing adoption }\end{array}$ & 3.97 & .134 \\
\hline $\begin{array}{l}\text { 3. Employees resistance to change from } \\
\text { traditional ways of doing work }\end{array}$ & 3.96 & .102 \\
\hline 4. Lack of technological readiness & 4.00 & .094 \\
\hline 5. Lack of IT-travel skilful labour & 4.00 & .145 \\
\hline $\begin{array}{l}\text { 6. Lack of public infrastructure readiness } \\
\text { (available and speed internet access) }\end{array}$ & 4.02 & .111 \\
\hline $\begin{array}{l}\text { 7. Viral marketing complexity } \\
\text { (complicated technology and not easy }\end{array}$ & 4.28 & .090 \\
\hline $\begin{array}{l}\text { 8. Lack of viral marketing successful and } \\
\text { proven business models }\end{array}$ & 4.00 & .146 \\
\hline $\begin{array}{l}\text { 9. Risk taking reluctance and uncertainty } \\
\text { of viral marketing benefits }\end{array}$ & 4.48 & .049 \\
\hline $\begin{array}{l}\text { 10. Business planning and strategy (no IT } \\
\text { strategy, no wish to expand) }\end{array}$ & 4.12 & .060 \\
\hline $\begin{array}{l}\text { 11. Legal concerns (taxation, liability } \\
\text { issues, privacy legislations, financial) }\end{array}$ & 4.35 & .060 \\
\hline \begin{tabular}{cl} 
12. Business & \multicolumn{2}{l}{ environment } & (political, \\
regulatory & systems and \\
consumer
\end{tabular} & 4.11 & .069 \\
\hline $\begin{array}{l}\text { 13. Lack of external support (Limited } \\
\text { governmental initiatives and support) }\end{array}$ & 4.23 & .062 \\
\hline $\begin{array}{l}\text { 14. Viral marketing is not suitable to the } \\
\text { nature of services }\end{array}$ & 4.22 & .089 \\
\hline
\end{tabular}




\section{Factor analysis of benefits of and barriers to viral marketing adoption}

\section{Factor analysis of perceived benefits of viral marketing adoption}

To categorize the benefits of viral marketing adoption in travel agents, factor analysis revealed three main groups of benefits (Table 3). It is obvious that 13 initial principal components (with 13 eigenvalues) have been produced. Only the first three have eigenvalues more than one using principal component analysis as an extraction method. About $80.49 \%$ of variance is explained by the first three factors, in other words $80.49 \%$ of the information contained in the 13 original variables can be explained by three unrelated components.

Table (3): Total Variance Explained in Benefits of Viral Marketing Adoption

\begin{tabular}{|c|c|c|c|c|c|c|}
\hline \multirow{2}{*}{ Component } & \multicolumn{3}{|c|}{ Initial Eigenvalues } & \multicolumn{2}{c|}{ Rotation Sums of Squared Loadings } \\
\cline { 2 - 7 } & Total & \% of Variance & Cumulative \% & Total & $\begin{array}{c}\text { \% of } \\
\text { Variance }\end{array}$ & Cumulative \% \\
\hline 1 & 6.008 & 46.214 & 46.214 & 4.512 & 34.704 & 34.704 \\
\hline 2 & 2.275 & 17.498 & 63.712 & 3.503 & 26.948 & 61.652 \\
\hline 3 & 2.181 & 16.779 & 80.490 & 2.449 & 18.838 & 80.490 \\
\hline 4 & .708 & 5.446 & 85.936 & & & \\
\hline 5 & .607 & 4.671 & 90.607 & & & \\
\hline 6 & .389 & 2.994 & 93.601 & & & \\
\hline 7 & .327 & 2.517 & 96.118 & & & \\
\hline 8 & .206 & 1.582 & 97.700 & & & \\
\hline 9 & .148 & 1.139 & 98.839 & & & \\
\hline 10 & .068 & .521 & 99.360 & & & \\
\hline 11 & .053 & .406 & 99.766 & & & \\
\hline 12 & .027 & .207 & 99.973 & & & \\
\hline 13 & .004 & .027 & 100.000 & & & \\
\hline
\end{tabular}

Kaiser-Meyer-Olkin Measure of sampling adequacy (KMO) is 0.470 , which means that the variables are meritorious and valid for factor analysis. Chi-square value is $2.217, \mathrm{df}=78$ and $\mathrm{P}<0.0 \mathrm{I}$ which leads to reject the null hypothesis suggesting that the correlation matrix is an identity matrix, where all the initial variables are uncorrelated, therefore the factor analysis is justifiable. Moreover, the determinant value $=1.68$ which is not equal to zero, meaning there were no linear dependences in the correlation matrix. From the rotated component matrix, Table (4) below shows that there are three groups of benefits, factor loadings below 0.50 have been suppressed according to Osborne and Costello (2009), and these factors are as follows.

Table (4): Rotated Component Matrix

\begin{tabular}{|l|l|l|l|}
\hline & \multicolumn{3}{l|}{ Component } \\
\hline & 1 & \multicolumn{1}{l|}{2} & 3 \\
\hline Reducing response time & .883 & & \\
\hline Improving customer satisfaction & $-.846-$ & & \\
\hline Encouraging customer loyalty & .842 & & \\
\hline Ease of carrying out transactions with customers & .825 & & \\
\hline Discounts, free products, or valuable information for customers & .799 & & \\
\hline Establishing reputation in the global markets & & .932 & \\
\hline Increasing potential for impact on the market & & .895 & \\
\hline Improving the company image & & .791 & \\
\hline Increasing customer's base & & .636 & \\
\hline Increasing brand awareness & & .600 & \\
\hline Increasing competitive advantage & & & .958 \\
\hline Taken advantage of existing resources & & & .879 \\
\hline Sales, revenue and profits growth & & & .717 \\
\hline
\end{tabular}


From table 4 three groups of benefits can be labelled as follows:

1. Customer-related benefits: it includes; reducing response time; improving customer satisfaction; encouraging customer loyalty; making it easier to carry out transactions with customers; and discounts, free products, or valuable information for customers.

2. Marketing-related benefits: it includes; establishing reputation in the global markets; increasing potential for impact on the market; improving the company image; increasing customer's base; and increasing brand awareness.

3. Managerial-related benefits: it includes; increasing competitive advantage; taken advantage of existing resources; and growth of sales, revenue, and profits.

\section{Factor analysis of perceived barriers to viral marketing adoption}

Running the factor analysis for barriers to viral marketing adoption, the analysis revealed three main categories of barriers (Table 5). The 14 initial principal components (with 14 eigenvalues) have been produced. Only the first three have eigenvalues more than one using principal component analysis as an extraction method. About $78.96 \%$ of variance is explained by the first three factors, in other words $78.96 \%$ of the information contained in the 14 original variables can be explained by three unrelated components.

Table (5 ): Total Variance Explained in Barriers to viral marketing adoption

\begin{tabular}{|c|c|c|c|c|c|c|}
\hline \multirow[b]{2}{*}{ Component } & \multicolumn{3}{|c|}{ Initial Eigenvalues } & \multicolumn{3}{|c|}{ Rotation Sums of Squared Loadings } \\
\hline & Total & $\%$ of Variance & Cumulative \% & Total & $\begin{array}{c}\% \text { of } \\
\text { Variance }\end{array}$ & $\begin{array}{c}\text { Cumulative } \\
\%\end{array}$ \\
\hline 1 & 4.707 & 33.621 & 33.621 & 4.654 & 33.242 & 33.242 \\
\hline 2 & 3.967 & 28.336 & 61.956 & 3.762 & 26.873 & 60.115 \\
\hline 3 & 2.381 & 17.010 & 78.967 & 2.639 & 18.851 & 78.967 \\
\hline 4 & .859 & 6.135 & 85.101 & & & \\
\hline 5 & .678 & 4.846 & 89.948 & & & \\
\hline 6 & .531 & 3.793 & 93.740 & & & \\
\hline 7 & .316 & 2.258 & 95.998 & & & \\
\hline 8 & .167 & 1.193 & 97.191 & & & \\
\hline 9 & .146 & 1.040 & 98.231 & & & \\
\hline 10 & .093 & .665 & 98.896 & & & \\
\hline 11 & .069 & .491 & 99.387 & & & \\
\hline 12 & .040 & .283 & 99.670 & & & \\
\hline 13 & .033 & .237 & 99.907 & & & \\
\hline 14 & .013 & .093 & 100.000 & & & \\
\hline
\end{tabular}

Kaiser-Meyer-Olkin Measure of sampling adequacy (KMO) is 0.558 , which means that the variables are meritorious and valid for factor analysis. Chi-square is $2.202, \mathrm{df}=91$ and $\mathrm{P}<0.0 \mathrm{I}$ which leads to the rejection of the null hypothesis suggesting that the correlation matrix is an identity matrix where all the initial variables are uncorrelated, therefore the factor analysis is justifiable. Moreover, the determinant value $=1.16$ indicating that there are no linear dependences in correlation matrix. From the rotated component matrix, Table 6 below shows that there are three groups of barriers, factor loadings below 0.50 have been suppressed according to Osborne and Costello (2009). 
Table (6): Rotated Component Matrix

\begin{tabular}{|l|l|l|l|}
\hline & \multicolumn{2}{|l|}{ Component } & 3 \\
\hline & 1 & 2 & \\
\hline Lack of Knowledge and/or awareness of viral marketing benefits & .924 & & \\
\hline Limited available resources for viral marketing adoption & .921 & & \\
\hline Employees resistance to change from traditional ways of doing work & .888 & & \\
\hline Viral marketing is not suitable to the nature of tourism services & .797 & & \\
\hline Business planning and strategy (no IT strategy, no wish to expand) & .750 & & \\
\hline Risk taking reluctance and uncertainty of viral marketing benefits & .656 & & .960 \\
\hline Lack of IT-travel skilful labour & .876 & \\
\hline Lack of public infrastructure readiness (available and speed internet access) & & .868 \\
\hline Lack of viral marketing successful and proven business models & & .693 & \\
\hline Lack of technological readiness & & .691 & \\
\hline Viral marketing complexity (complicated technology and not easy to be used) & & & .896 \\
\hline Legal concerns (taxation, liability issues, privacy legislations, financial) & & .869 \\
\hline Business environment (political, regulatory systems and consumer culture) & & & .630 \\
\hline Lack of external support (Limited governmental initiatives and support) & & \\
\hline
\end{tabular}

From Table 6, the three groups of barriers can be categorized as follows:

1. Organizational barriers: this includes; lack of awareness of viral marketing benefits, limited available resources for viral marketing adoption, employees resistance to change from traditional ways of doing work, viral marketing is not suitable to the nature of tourism services, business planning and strategy (no it strategy, no wish to expand), and risk taking reluctance and uncertainty of viral marketing benefits.

2. Technical barriers: it includes; lack of it-travel skilful labour, lack of public infrastructure readiness, lack of viral marketing successful and proven business models, and lack of technological readiness.

3. Environmental barriers: it includes; legal concerns (taxation, liability issues, privacy legislations, financial), business environment (political, regulatory systems and consumer culture), and lack of external support (limited governmental initiatives and support).

\section{Regression analysis of perceived benefits of viral marketing adoption}

Covering the first objective of the study identifying the benefits of viral marketing adoption, multiple regression analysis was used. It is found that $\mathrm{R}$ square value is 0.60 , from travel agents manager's perspectives, which indicates $60 \%$ of the variance in the benefits scores accounted for the set of predictor variables. In addition, the analysis revealed $\mathrm{F}_{(3,126)}$ value of 57.85 , and $\mathrm{p}<.01$, which proved the overall significance of the model. Table 7 depicts the beta values of the produced benefits.

Table 7 Regression analysis of benefits of viral marketing adoption

\begin{tabular}{|l|l|l|l|}
\hline Model & Beta & T value & Sig. \\
\hline (Constant) & 2.777 & 34.349 & .000 \\
\hline Customer-related benefits & 0.580 & 7.148 & .000 \\
\hline Marketing-related benefits & 0.787 & $-9.700-$ & .000 \\
\hline Managerial-related benefits & 0.432 & 5.326 & .000 \\
\hline
\end{tabular}

From table 7 , it is obvious that managerial-related benefits $(b=0.0432$, and $p<0.01)$, has the greatest benefits of viral marketing adoption from the managers' perspective. This is followed by customer-related benefits $(b=\cdot, 580$, and $\mathrm{p}<0.01)$, then marketing-related benefits $(\mathrm{b}=0.0787$ and $\mathrm{p}<.01)$. These findings lead to accept the first hypothesis of the study; there is a positive causal relationship between the perceived benefits of adoption and viral marketing adoption in Egyptian travel agents.

From these results, it is clear that there are many benefits of viral marketing adoption. First managerial benefits such as; increasing competitive advantage, taken advantage of existing resources, and growth of sales, revenue and profits. Second, customer-related benefits such as; reducing response time, improving customer satisfaction, encouraging customer loyalty, and discounts, free products, or valuable information for customers. Third, marketing- 
related benefits such as; establishing reputation in the global markets, increasing potential for impact on the market, improving the company image, increasing customer's base, and increasing brand awareness.

This finding is in line with Dobele et al. (2005) who studied spreading the brand message through viral marketing. They found that viral marketing could drive sales, reduce marketing costs, and reach target consumer segments. In addition, Thevenot, et al. (2001) who studied viral marketing and found the technique is valuable for both customers and companies. Customers get things they want, such as discounts, free products, or valuable information. For companies, it is an inexpensive way to establish themselves, grow their brand, and increase their customer base. Moreover, Deepa and Thenmozhi (2013) who studied viral marketing as an on-line marketing medium and found viral marketing is popular because of the ease of executing the marketing campaign, relative low-cost, good targeting, the high and rapid response rate, and the ability to obtain a large number of interested people at a low cost.

\section{Regression analysis of perceived barriers to viral marketing adoption}

To cover the second objective of research identifying the barriers to viral marketing adoption in travel agents, a multiple regression analysis was used. It is found that $\mathrm{R}$ square value is 0.80 , from managers' perspectives, which indicates $80 \%$ of the variance in the barriers scores accounted for by our set of predictor variable. In addition, the analysis revealed $\mathrm{F}$ $(3,123)$ value of 169.63 , and $\mathrm{p}<.01$, which leads to decide that the model is significant.

Table (8): Regression analysis of barriers to viral marketing adoption

\begin{tabular}{|c|c|c|c|}
\hline Model & B & $\mathrm{T}$ value & Sig. \\
\hline (Constant) & 2.748 & $\leq 9, r \leqslant 1$ & .000 \\
\hline Organizational Barriers & .799 & $-1 \varepsilon, Y T Y_{-}$ & .000 \\
\hline Technical Barriers & .979 & $-\perp \vee, \Sigma \vee \Lambda_{-}$ & .000 \\
\hline Environmental Barriers & .005 & $-. \wedge 1 .-$ & .936 \\
\hline
\end{tabular}

From table 8 , organizational barriers $(b=0.799$ and $p<.01)$, have the greatest barriers of viral marketing adoption from the managers' perspective. This is followed by technical barriers $(b=0.979$, and $p<0.01)$, then environmental barriers $(b=0.005$, and $p=0.936)$. From these results, it is clear that travel agents managers agree that there are barriers to viral marketing adoption. This finding leads to accept the second hypothesis that "There is a negative causal relationship between the perceived barriers to adoption and viral marketing adoption in Egyptian travel agents". This finding is consistent with the literature studies of Abou-Shouk (2012) who studied E-commerce adoption in SMEs tourism enterprises in Egypt. He found similar findings citing that lack of awareness of technology adoption, limited resources, resistance to change and risk taking reluctance, business characteristics, business planning, and strategy. Moreover, lack of technological readiness, lack of skilled labour, legal concerns, and security issues, business environment, lack of public infrastructure readiness, lack of external support and successful role models, technology attributes, and the cost of technology implementation cited as barriers to adopt E-commerce. In addition Grifoni et al. (2013) who studied an integrated framework for on-line viral marketing campaign planning and found viral marketing presents limitations related to: technical problems or poor technological implementation; lack of control over message and reach, legal issues dealing with privacy and harassment; lack of measurement and uncharted growth in unexpected areas.

\section{Conclusion and Recommendations}

Over the years, internet marketing has become the primary tool for marketers to deliver information to consumers. It includes a mix of methods (m-marketing, social networks, viral marketing etc.) to create awareness for the company's brand, products, and services. This study has determined the perceived benefits of and barriers to viral marketing adoption of Egyptian travel agents in Egypt. This paper has met its two objectives; depicting the perceived benefits of viral marketing adoption by travel agents managers and categorizing the perceived barriers to adoption in travel agents.

The main findings of the study are; viral marketing adoption has several benefits of Egyptian travel agents. First managerial benefits such as; increasing competitive advantage, taken advantage of existing resources, and growth of sales, revenue and profits. Second, customer-related benefits such as; reducing response time, improving customer satisfaction, encouraging customer loyalty, and discounts, free products, or valuable information for customers. Third, marketing-related benefits such as; establishing reputation in the global markets, increasing potential for impact on the market, improving the company image, increasing customer's base, and increasing brand awareness.

Despite these advantages, there are several barriers to adopt viral marketing in travel agents in Egypt. First organizational barriers such as; lack of awareness of viral marketing, limited available resources for its adoption, employees resistance to change, and risk taking reluctance and uncertainty of viral marketing benefits. Second technical barriers; it includes; lack of it-travel skilful labour, lack of public infrastructure readiness, lack of viral marketing successful and proven business models, and lack of technological readiness. Third environmental barriers; it includes; legal concerns, business environment (political, regulatory systems and consumer culture), and lack of external support. This study is useful for governmental bodies and travel agencies to take action to adopt viral marketing in their 
activities. To form the road map of viral marketing adoption and to take the full advantages of it, travel agencies have to recognize the benefits they can gain from viral marketing adoption and develop their viral marketing readiness to highlight the group of benefits they need more. Moreover, they should work on the existence of solutions and overcome the obstacles to the adoption of viral marketing. They may focus on transactions easiness, market expansion or marketing efforts and that relates directly to the level of viral marketing adoption they adopt.

\section{Limitations and Future Research}

When reviewing this study, some limitations were found. First, the study investigates the perceptions of travel agents regarding viral marketing adoption and not the actual realized benefits or the actual barriers hindering adoption. Thus, benefits and barriers are used in this study as antecedents and not consequences of adoption. Comparing the perceived against the actual benefits and barriers could be interesting area for future research. The study is restricted to Category 'A' travel agents, excluding Categories 'B' and 'C'. Category 'A' travel agents were selected because they are licensed to work locally and globally, and their capital and activities could allow them to adopt viral marketing and enhance their competitive position and operational efficiency. The insights revealed by this study should help these agents to survive in the global travel market.

Regarding sampling limitations, selecting Greater Cairo as the geographical sampling frame restricted the data collected to a large part of Egypt but not all of it. In addition, further research should be addressed to investigate the perceptions of employees in Egyptian travel agent and the perceptions of customers regarding viral marketing benefits. One more limitation of this study is the need for qualitative interviews to confirm these groups of benefits and barriers and their priorities for travel agents. Thus, future research should address the identified benefits of and barriers to adoption, with a stronger focus on the adoption level to distinguish how the barriers and benefits relate to each level. This will help the managers of travel agencies to understand the benefits and barriers related to their particular level of adoption. Policy makers could also benefit as they could take initiatives and actions towards addressing these barriers to adopt viral marketing in their activities.

\section{References}

Abou-Shouk, M. (2012). Investigating E-Commerce Adoption in Small and Medium-Sized Tourism Enterprises: A Case of Travel Agents in Egypt. A Thesis Submitted in Partial Fulfillment For The Degree Of Doctor Of Philosophy. School Of Tourism and Hospitality. Faculty of Plymouth Business School. Plymouth. U.K.

Alipour, M., Hajaliakbari, F., and Javanbakht, N. (2011). The Impact of Web-Marketing Mix (4s) on Development of Tourism Industry in Iran. International Journal of Business and Social Science, 2 (6), 267-274.

Alkharabsheh, K. S., ALsarayreh, M. N., Abu Rumman, M., and AL farajat, A. H. (2011). The Impact of Viral Marketing via Internet on Promotion of Tourism Products in Jordan. International Research Journal of Finance and Economics(80), 138-147.

Anderson, S. (2008). Using Social Networks to Market. Rough Notes, 151(2), 114-115.

Anonymous. (2010). 21 Tips to Viral Marketing Success! Retrieved 28-9, 2013, from http://worldprofitassociates.com/sites

Argentini, P., and Barnes, C. (2009). Digital Strategies for Powerful Corporate Communication McGraw - Hill, New York.

Armstrong, G., and Kotler, P. (2011). Marketing: An introduction. Boston: Prentice Hall.

Bampo, M., Ewing, M. T., Mather, D. R., Stewart, D., and Wallace, M. (2008). The effects of the social structure of digital networks on viral marketing performance. Information Systems Research, 19(3), 273-290.

Bannan, K. J. (2000). It's catching. Brandweek, 41(23), 20-27.

Beekhuyzen, J., Hellens, L., and Siedle, M. ( 2005). Cultural barriers in the adoption of emerging technologies Retrieved $27 \quad$ October, 2013, from http://140.131.24.185/profrtlin/Research_theory_Data/F.2005HCI\%E6\%96\%87\%E5\%8C\%96\%E8\%AB\%96\%E6\%96\%87/1813.pdf

Bernoff, J., and Li, C. (2008). Harnessing the Power of the Oh-So-Social 134 Web. MIT Sloan Management Review, 49(3), 36-42.

Best, R. J. (2009). Market-Based Management: Strategies for Growing Customer Value and Profitability ( 5th ed.): Pearson Education, New Jersey.

Bonera, M. (2010). How Are The Operators In The Tourism Industry Approaching The Virtual Channel. International Review of Business Research Papers, 6 (1), 157-169.

Boone, L. E., and Kurtz, D. L. (2011). Contemporary Marketing. Mason: South-Western. 
Bruyn, A. D., and Lilien, G. L. (2008). A multi-stage model of word of-mouth influence through viral marketing. International Journal of Research in Marketing, 25, 151-163.

Castronovo, C., and Huang, L. (2012). Social Media in an Alternative Marketing Communication Model. Journal of Marketing Development and Competitiveness, 6(1) 117-134.

Chaffey, D. (2006). Total E-mail Marketing (2nd ed.). Oxford, England.: Butterworth-Heinemann.

Chiu, H.-C., Yi-Ching Hsieh, Ya-Hui Kao, and Lee, M. (2007). The Determinants of Email Receivers' Disseminating Behaviors on the Internet. Journal of Advertising Research, 47(4), 524-534.

Cruz, D., and Fill, C. (2008). Evaluating Viral Marketing: Isolating the Key Criteria. Marketing Intelligence and Planning, 26(7), 743-758.

Datta, P. R., Dababrata N. Chowdhury, and Chakraborty, B. R. (2005). Viral Marketing: New form of Word-of-Mouth through Internet. The Business Review, 3(2), 69-75.

Deepa, N., and Thenmozhi, S. (2013). Viral Marketing as an On-Line Marketing Medium. IOSR Journal of Business and Management (IOSR-JBM), 88-94.

Dinh, T. N., Nguyen, D. T., and Thai, M. T. (2012). Cheap, Easy, and Massively Effective Viral Marketing in Social Networks: Truth or Fiction? . Paper presented at the the 23rd ACM conference on Hypertext and social media, ACM New York, NY, USA.

Dobele, A., Lindgreen, A., Beverland, M., Vanhamme, J., and Wijk, R. v. (2007). Why pass on viral messages? Because they connect emotionally. Journal of Business Horizons, 50 (4), 291- 304.

Dobele, A., Tolemanb, D., and Beverlandb, M. (2005). Controlled Infection! Spreading the Brand Message through Viral Marketing. Business Horizons, 48, 143-149.

Domingos, P. (2005). Mining Social Networks for Viral Marketing. IEEE Intelligent Systems, 20 (1), 80-82.

Egyptian Travel Agents Association. (2013). Agencies Directory. Cairo, Egypt: ETTA: Ministry of Tourism.

Ferguson, R. (2008). Word of mouth and viral marketing: taking the Temperature of the hottest trends in marketing. Journal of consumer marketing, 25 (3), 179-182.

Fritz, W. (2004). Internet-Marketing und Electronic Commerce (3rd Edition ed.): Wiesbaden: Gabler Verlag.

Grifoni, P., D'Andrea, A., and Ferri, F. (2013). An Integrated Framework for On-line Viral Marketing Campaign Planning. International Business Research, 6(1), 22-30.

Gruen, T. W., Osmonbekov, T., and Czaplewski, A. J. (2006). eWOM: The impact of customer-to-customer online know-how exchange on customer value and loyalty. Journal of Business. Research, 59(4), 449-456.

Guthan, A. (2002). The Impact of the Internet on Business Travel”. MA European Tourism Management, . Bournemouth University. U.K.

Hassan, S., and Soliman, M. (2013). Travel Agencies Management: Faculty of Tourism and Hotels. Fayoum University, Egypt.

Helm, S. (2000). Viral Marketing - Establishing Customer Relationships by "Word of Mouse". Electronic Markets, 10 (3), 158-161.

Herbig, P. (2011). Viral Marketing - what we want our customers to catch Retrieved 29 September, 2013, from http://www.docstoc.com/docs.

Ho, J. Y. C., and Dempsey, M. (2009). Viral marketing: Motivations to forward online content. Journal of Business Research, 63(9/10), 1000-1006.

Johnstone, D. A., and Wright, L. (2004). The E-Business capability of small and medium sized firms in international supply chains. Information Systems and E-Business Management, 2, 223-240.

Jurvetson, S. (2000). What exactly is viral marketing? Red Herring, 78, 110-112.

Jurvetson, S., and Draper, T. (1997). Viral Marketing.” Netscape M files, 1997, and edited version Business 2.0, 1998.

Khosravani, K. (2009). Viral Marketing Riches. At Retrieved 15 october, 2013, from www.web2marketingsystems.com

Kirby, J. (2004). Online viral marketing; the strategic synthesis in peer-to-peer brand marketing. Brand Channel White Paper: Digital Media Communications Ltd. U.K. 
Kohn, S., and Husig, S. (2006). Potential benefits, current supply, utilization and barriers to adoption: an exploratory study of German SMEs and innovation software. Technovation, 26(1), 988-998.

Konecnik, M. (2002). The image as a possible source of competitive advantage of the destination: The case of Slovenia. Tourism Review, 57 (1/2), 6-12.

Kozinets, R. V., Kristine, d. V., Andrea, C. W., and Sarah, J. S. W. (2010). Networked Narratives: Understanding Word-of-Mouth Marketing in Online Communities. Journal of Marketing, 74, 71-89.

Laudon, K. C., and Traver, C. G. (2001). E-commerce: Business, technology, society. Boston: Addison-Wesley.

Leskovec, J., Adamic, L. A., and Huberman, B. A. (2007). The dynamics of viral marketing. ACM Transactions on the Web, 1 (1) Article 5.

Lewis, R., and Cockrill, A. (2002). Going global- Remaining local. The impact of e-commerce on small retail firm in Wales. International Journal of Information Management, 22, 195-209.

Migiro, S., and Adigun, M. ( 2005). ICTs, E -commerce and rural development: the case of arts and crafts SMEs in rural Kwazulu-Natal. Research Paper University of Zululand, 65-80,.

Osborne, J. W., and Costello, A. B. (2009). Best practices in exploratory factor analysis: Four recommendations for getting the most from your analysis. Pan-Pacific Management Review, 12(2) 131-146.

Panchanathan, N. (2005). Current Trends in Internet Marketing. Master Thesis in Business Administration, Blekinge Institute of Technology (BTH). School Of Management. Blekinge, Sweden.

Patel, N. K. (2007). Internet Based Viral Marketing for Global Competition: The Road Ahead: Centre for Management Studies, Dharmsinh Desai University Nadiad. India.

Phelps, J. E., Lewis, R., Mobilio, L., Perry, D., and Raman, N. (2004). Viral Marketing or Electronic Word-of-Mouth Advertising: Examining Consumer Responses and Motivations to Pass Along Email. Journal of Advertising Research, 44(4), 333-348.

Plummer, J., Rappaport, S., Hall, T., and Barocci, R. (2007). The Online Advertising Playbook : Proven Strategies and Tested Tactics from the Advertising Research Foundation. New Jersey: John Wiley and Sons, Inc.

Porter, L., and Golan, G. J. (2006). From Subservient Chickens to Brawny Men: a Comparison of Viral Advertising to Television Advertising. Journal of Interactive Advertising, 6(2), 30-38.

Richter, K. (2012). Viral Destination Marketing Science rather than Art!? A European Perspective Retrieved 22 October, 2013, from www.forum.czechtourism.cz

Riege, A. M., Perry, C., and Go, F. M. (2002). Partnerships in international travel and tourism marketing: a systemsoriented approach between Australia, New Zealand, Germany and the United Kingdom. Journal of Travel and Tourism marketing, 11(1), 59-77.

Saunders, M., Thornhill, A., and Lewis, P. (2009). Research methods for business students ((5th ed.) ed.). London: Financial Times Prentice Hall.

Schiffman, G. L., and Kanuk, L. L. (2010). Consumer Behavior (10th Edition ed.): Prentice Hall.

Scott, D. M. (2007). the New Rules of Marketing and PR. How to Use News Releases, Blogs, Podcasting, Viral Marketing, and Online Media to Reach Buyers Directly. Hoboken, New Jersey: John Wiley and Sons, Inc.

Skrob, J.-R. (2005). Open Source and Viral Marketing: The viral marketing concept as a model for open source software to reach the critical mass for global brand awareness based on the example of TYPO3. : University of Applied Science Kufstein, Austria.

Sohn, K., Gardner, J. T., and Weaver, J. L. (2013). Viral Marketing - More than a Buzzword. Journal of Applied Business and Economics, 14(1), 21-42.

Sprong, E. H. C. (2010). From viral marketing to epidemics: Message and sender characteristics to increase the intention to forward. Master Thesis Marketing, Erasmus University Rotterdam.

Stansfield, M., and Grant, K. (2003). An investigation into issues influencing the use of the Internet and electronic commerce among small-medium sized enterprises. Journal of Electronic Commerce Research, 4(1), 15-33.

Steyer, A., Renaud, G.-B., and Pascale, Q. (2007). Modélisation de la Structure Sociale des Groupes de Discussion sur Internet : Implications pour le Contrôle du Marketing Viral. Recherche et Applications en Marketing, 22(3), 29-44.

Subramani, M. R., and Rajagopalan, B. (2003). Knowledge-sharing and influence in online social networks via viral Marketing. Communications of the ACM, 46 (12), 300-307. 
Thevenot, C., Watier, K., and Team Member. (2001). Viral Marketing. Georgetown University, Communications, Culture and Technology Program, May 2001. Retrieved 30 septmber, 2013, from www.watier.org/kathy/papers/ViralMarketing.doc

Van der Lans, R., Van Bruggen, G., Eliashberg, J., and Wierenga, B. (2010). A viral branching model for predicting the spread of electronic word of mouth. Marketing Science, 29(2), 348-365.

Watts, D. J., Peretti, J., and Frumin, M. (2007). Viral marketing for the real world. Harvard Business Review, 85 (5), $22-23$.

Wilson, R. F. (2012). the six simple principles of viral marketing. Web Marketing Today. Editor's Note: Dr. Wilson first published this article in 2000. He then updated it in 2005. Then updated it a third time, in 2012 Retrieved 30 September, 2013, from http://webmarketingtoday.com/articles/viral-principles/

Woerndl, C., Papagiannidis, S., Bourlakis, M. A., and Li, F. (2008). Internet-induced marketing techniques: Critical factors in viral marketing campaigns. International Journal of Business Science and Applied Management, 3 (1), 33 45 .

Xavier, L. J. W., and Summer, G. Y. S. (2009). Viral Marketing Communication: The Internet Word-of-Mouth. A study on consumer perception and consumer response. Master Thesis in Business Administration. School of Management. Blekinge Institute of Technology.

Xiong, L., and Hu, C. (2011). Hotel Viral Marketing via Social Networks: A Strategic Pricing Lesson from Group Buying: UMass Amherst. U.S.A.

Yasin, N. M., and Zahari, A. R. (2011). Does Family And Viral Marketing Have Any Effect On Brand Equity? Contemporary Marketing Review, 1(9), 01 - 13.

Zhang, H., Q. , and Morrison, A. (2007). How can the small to medium sized travel agents stay competitive in China's travel service sector? International Journal of Contemporary Hospitality Management, 19, 275-285.

$$
\text { تطبيق التسويق الفيروسي داخل شركات السياحة المصرية: الفوائد والمعوقات المدركة }
$$

تسعي معظم المؤسسات السياحية للبحث عن أدوات جديدة ومتطورة للوصول إلى الأسواق المستهدفة بطريقة أكثر كفاءة وفعالية. ومع تطوير

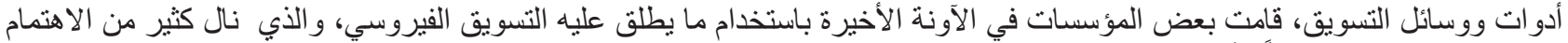

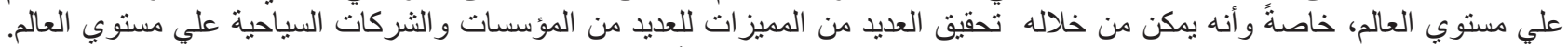

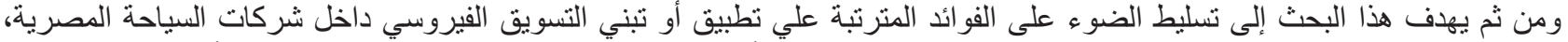

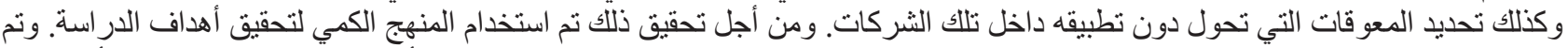

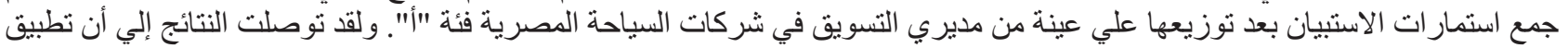

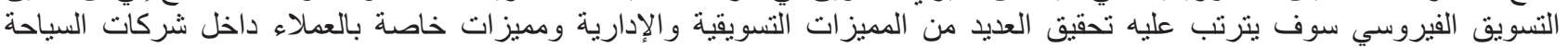
المصرية. بالإضافة إلى أن هناك مجموعة من المعوقات التنظيمية والبيئية والتقنية التي تحول دون تطبيق التسويق الفيروسي داخل شركات السياحة المصرية. الكلمات الدالة: التسويق الفيروسي؛ الفو ائد؛ المعوقات؛ شركات السياحة؛ مصر 